\title{
"The IPO initial returns-aftermarket risk question revisited: evidence from firms in Taiwan"
}

\begin{tabular}{|c|c|c|}
\hline AUTHORS & \multicolumn{2}{|l|}{$\begin{array}{l}\text { Fong-Yi Shen } \\
\text { Yeong-Jia Goo }\end{array}$} \\
\hline ARTICLE INFO & \multicolumn{2}{|c|}{$\begin{array}{l}\text { Fong-Yi Shen and Yeong-Jia Goo (2019). The IPO initial returns-aftermarket risk } \\
\text { question revisited: evidence from firms in Taiwan. Investment Management and } \\
\text { Financial Innovations, 16(2), 14-24. doi:10.21511/imfi.16(2).2019.02 }\end{array}$} \\
\hline DOI & \multicolumn{2}{|c|}{ http://dx.doi.org/10.21511/imfi.16(2).2019.02 } \\
\hline RELEASED ON & \multicolumn{2}{|l|}{ Friday, 12 April 2019} \\
\hline RECEIVED ON & \multicolumn{2}{|l|}{ Thursday, 07 March 2019} \\
\hline ACCEPTED ON & \multicolumn{2}{|l|}{ Monday, 08 April 2019} \\
\hline & \multicolumn{2}{|l|}{$(\mathrm{cc}) \mathrm{EY}$} \\
\hline LICENSE & \multicolumn{2}{|c|}{$\begin{array}{l}\text { This work is licensed under a Creative Commons Attribution } 4.0 \text { International } \\
\text { License }\end{array}$} \\
\hline JOURNAL & \multicolumn{2}{|c|}{ "Investment Management and Financial Innovations" } \\
\hline ISSN PRINT & \multicolumn{2}{|l|}{$1810-4967$} \\
\hline ISSN ONLINE & \multicolumn{2}{|l|}{$1812-9358$} \\
\hline PUBLISHER & \multicolumn{2}{|c|}{ LLC “Consulting Publishing Company "Business Perspectives" } \\
\hline FOUNDER & \multicolumn{2}{|c|}{ LLC “Consulting Publishing Company "Business Perspectives” } \\
\hline \multirow[b]{2}{*}{ NUMBER OF REFERENCES } & & $\begin{array}{l}\text { ニ-̃ } \\
\text { ニE- }\end{array}$ \\
\hline & NUMBER OF FIGURES & NUMBER OF TABLES \\
\hline 39 & 0 & 4 \\
\hline
\end{tabular}

(C) The author(s) 2023. This publication is an open access article. 


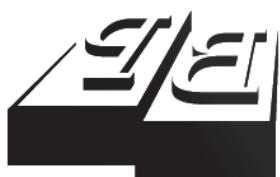

BUSINESS PERSPECTIVES

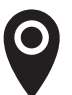

LLC "CPC "Business Perspectives" Hryhorii Skovoroda lane, 10, Sumy, 40022, Ukraine

www.businessperspectives.org

Received on: $7^{\text {th }}$ of March, 2019 Accepted on: $8^{\text {th }}$ of April, 2019

(c) Fong-Yi Shen, Yeong-Jia Goo, 2019

Fong-Yi Shen, Ph.D. Candidate, Department of Business Administration, National Taipei University, Taiwan.

Yeong-Jia Goo, Professor, Department of Business Administration, National Taipei University, Taiwan.
THE IPO INITIAL RETURNSAFTERMARKET RISK QUESTION REVISITED: EVIDENCE FROM FIRMS IN TAIWAN

\begin{abstract}
The purpose of this study is to utilize the Three Stage Least Squares (3SLS) of the simultaneous equation estimation approach to revisit the possible cross relationship between IPO initial returns and aftermarket risk. A structural form equation system of IPO initial returns and aftermarket risk equations is estimated first to obtain the structural form coefficients. The analytically derived reduced form coefficients are then calculated to analyze the net effects of each exogenous variable on two endogenous variables. Major findings of this study are as follows. First, the signs of net effects of all exogenous variables on IPO initial returns and aftermarket risk are the same. In other words, any change in exogenous variables, IPO initial returns and IPO aftermarket risk will change in the same direction, i.e., the higher (lower) the IPO initial returns, the higher (lower) the IPO aftermarket risk. Second, the less the degree of corporate governance, the higher the IPO initial returns and aftermarket risk. Third, the higher the market risk or return before IPO, the higher the IPO initial returns and aftermarket risk.
\end{abstract}

Keywords IPO, initial returns, aftermarket risk, 3SLS

JEL Classification $\quad$ G10, G12, G40

\section{INTRODUCTION}

The abnormal returns of initial public offerings (IPO) or the so-called IPO initial returns have always been one of the most popular areas heavily studied by finance academics. Two major hypotheses, the asymmetric information and the market overreaction hypotheses, of the IPO initial returns have been proposed in most literature. The hypothesis of asymmetric information states that IPO initial returns are resulted from asymmetric information between/among underwriters, IPO companies, and investors (Baron, 1982; Rock, 1986; Chalk \& Peavy, 1987; Carter \& Manaster, 1990; Gompers, 1996; Welch, 1989; $\mathrm{Ma} \& \mathrm{Hu}, 2003)$. The market overreaction hypothesis argues that IPO initial returns are consequences of IPO aftermarket overreaction, price stabilization policy of the underwriters, and effects of speculation bubbles (Ritter, 1984; Rock, 1986; Booth \& Smith, 1986; Aggarwal \& Rivoli, 1990; Chemmanur, 1993; Ruud, 1993; Chowdhry \& Nanda, 1996; Cassia et al., 2004; Ma \& Hu, 2003; Peng \& Wang, 2007). Among these, the aftermarket risk is found to have positive impact on IPO initial returns (Ritter, 1984; Aggarwal \& Rivoli, 1990; Ruud, 1993; Chowdhry \& Nanda, 1996; Cassia et al., 2004; Peng \& Wang, 2007).

By contrast, Sherman (2005) focused on how IPO initial returns affect the aftermarket price fluctuation. Theoretical derivation found that if a country switches from auctions to bookbuild IPOs, underpricing is expected to increase, but because more information is produced in the 
IPO, aftermarket volatility is expected to decrease. Pettway et al. (2008) applied empirical data of Japan to discuss the influence of IPO initial returns on aftermarket fluctuation as a component of the aftermarket risk is ex-ante firm risk. However, their conclusions were opposite to Sherman's findings. The IPO initial returns are found to be positively correlated to IPO aftermarket risk. Gleason et al. (2008) also used initial returns as the independent variable to analyze the effect of IPO underpricing on aftermarket short-term and long-term volatilities of stock returns. Results showed that the higher the IPO initial returns are, the higher the IPO aftermarket risk is for venture-backed issuing company.

Previous studies on the relationship between initial returns and aftermarket risk are all estimated and tested using single equation approach. In other words, the effect of initial returns on aftermarket risk and vice versa are all estimated and tested under ceteris paribus assumption. However, according to the above-mentioned IPO-related empirical documents, there may exist a simultaneous relationship between IPO initial returns and aftermarket risk ${ }^{1}$. The purpose of this study is to utilize the Three Stage Least Squares (3SLS) of the simultaneous equation estimation method to analyze the simultaneous relationship between IPO initial returns and aftermarket risk. A structural form equation system of IPO initial returns and aftermarket risk equations is estimated first to test and obtain the structural form coefficients. The analytically derived reduced form (ADRF) coefficients are then calculated to analyze the net effects of each exogenous variable on two endogenous variables.

This study is the first attempt in literature to investigate the simultaneous relationship between IPO initial returns and aftermarket risk using a total of 637 IPO company data in Taiwan for the period 1997-2008. While most previous literature focused on IPO initial returns, this study turns more attention to IPO aftermarket risk. Variables of the deviations of seat control to voting right and voting right to cash right will be considered in the model to investigate the importance of corporate governance to aftermarket risk. The simultaneity of IPO initial returns and aftermarket risk is then considered to find out their actual relationship. The net effects of exogenous variables on IPO initial returns and aftermarket risk are then lastly presented.

\section{LITERATURE REVIEW}

The first major hypothesis of the IPO initial returns is the asymmetric information hypothesis. The hypothesis of asymmetric information assumes that IPO initial returns are resulted from asymmetric information between/among underwriters, IPO companies, and investors. Baron (1982) believed that there exists asymmetric information between IPO companies and underwriters. Therefore, IPO companies tend to underprice the offer price when facing higher uncertainty in stock market. Rock (1986) proposed "the winners' curse" hypothesis where IPO underpricing is a result of asymmetric information between well-informed and uninformed investors in the market. Chalk and Peavy (1987), Carter and Manaster (1990), and Gompers (1999) later extended Rock's theory to incorporate the ex-ante uncertainty to explain the IPO underpricing. Welch (1989) and $\mathrm{Ma}$ and $\mathrm{Hu}$ (2003) believed that there exists asymmetric information between IPO companies and investors. They proposed the signaling hypothesis and suggested that IPO initial returns are not related to the costs of information collection, but related to the quality of IPO companies' signals to investors.

Later, Bouzouita, Gajewski, and Gresse (2015), using a sample of IPOs from Euronext, found that analyst coverage engendered by initial underpricing reduces information asymmetry costs. Their results showed that the impact of information asymmetry on measures based on adverse selection costs is statistically more significant than those on the proportion of informed traders in the market. Boulton, Smart, and Zutter (2017) exam-

1 If initial return is endogenously determined with aftermarket risk through aftermarket risk function, then single equation OLS estimates will be biased and inconsistent. Hausman (1978) originally proposed a test statistic for endogeneity based upon a direct comparison of coefficient values. Here, we utilize the version of the Hausman test proposed by Davidson and MacKinnon $(1989,1995)$, which carries out the test by running an auxiliary regression. Results show that the test significantly rejects the hypothesis of consistent OLS estimates. In other words, the endogeneity is present and a simultaneous equation approach is more appropriate than single equation approach. 
ined 13,285 IPOs from 36 countries. They found that IPOs are underpriced less in countries in which the existing public firms practice more accounting conservatism. Results above are consistent with the hypothesis that conservatism reduces underpricing by mitigating the impact of information asymmetries. By introducing firm's growth as the information which has triggered many investors to behave overconfidently, Raharja, Suhaeli, and Mranani (2017) found that investors tend to behave overconfidently to higher growth firms. They also found that higher growth firms tend to have declining performance in the future. The negative relation between firms' growth and longterm performance indicates that the price reversal is caused by investor's overconfidence. Recently, Zhou and Sadeghi (2019) investigated whether R\&D spending, characterized by information asymmetry and valuation uncertainty, will aggravate IPO underpricing, using 1,460 IPOs from Chinese stock markets. They conversely found a positive signal effect for patents, which may reduce the extent of IPO underpricing significantly. Results indicate that public disclosure of information pertaining to innovation will help issuers to reduce their IPO costs.

The second major hypothesis of the IPO initial returns is the market overreaction hypothesis. Different from the asymmetric information hypothesis, the market overreaction hypothesis states that IPO initial returns are consequences of IPO aftermarket overreaction, price stabilization policy of the underwriters, and effects of speculation bubbles. Rock (1986) and Chemmanur (1993) found that there was a significant relationship between economic condition and the magnitude of underpricing. The magnitude of IPO underpricing would be smaller when economy is in good condition. $\mathrm{Ma}$ and $\mathrm{Hu}$ (2003) found that other than underestimated by underwriters, market overreaction might also be a reason, and the lower the underwriting price, the more market participants. This was the so-called "purchase signal". When an IPO company expected more "purchase signals", its price will be underpriced more, representing higher market reaction.

Smith (1986) believed that the underwriters might try to stabilize the stock price after IPO if they were worried that stock price will be lower than the offer price and, thus, jeopardizing company's reputation. Therefore, price stabilization policy of underwriter particularly influenced IPO initial returns. Ruud (1993) also stated that the distribution of IPO initial returns would tend to have a positive skewness with a peak around zero. He believed that this was the result of aftermarket price stabilization policy used by the underwriter. Aggarwal and Rivoli (1990) focused on the returns of stocks listed after 250 days. They found that there exists no underestimation in underwriting price. Due to good market condition, overoptimistic by investors, or excess demand by investors who missed buying IPO stocks during underwriting period, there will be created the "fads" after IPO and stock prices will be overpriced temporarily. After speculation bubbles are broken, the excess returns might be reversed due to the correction of misrecognition. This also explained why the stock prices of some IPO companies did not enjoy a positive long-term performance.

Later, Vakrman and Kristoufek (2015) proxy the investor's attention before and during the day of the offering using the Internet searches on Google. They found that investor's attention remains a strong component of the high initial returns, primarily for the high sentiment periods. They further demonstrate that the investor's attention partially explains the overoptimistic market reaction and thus also a part of the long-term underperformance. Malhotra and Nair (2105) examined the first day returns of 288 book-built IPOs in India for the period from 2004 to 2010 . Results showed that over-subscription and market volatility were the major factors influencing Indian IPO underpricing, implying that Indian investors overreact to the market. Deng and Zhou (2016) hypothesized that the initial return contains a fundamental underpricing, represented by the 21 st day return, and an overreaction, represented by the difference between the initial and 21st day returns. They found that initial return is driven more by short-term and market factors that cause overreaction and the 21st day return is affected more by an issuer's fundamentals. Recently, Komenkul, Sherif, and $\mathrm{Xu}$ (2017) used the market-feedback hypothesis to investigate the signaling effects for the detection of speculative stocks in relation to the degree of their prior IPO underpricing. By using a unique data set from Thai stock market of the so-called 
'Turnover List (TOL)', they found a significant positive relationship between the magnitudes of the IPO underpricing and the probability of an IPO firm being classified officially as speculative on the TOL. They further found that 6-month abnormal return after going public increases the probability of speculative dealing in the IPOs.

The above-mentioned studies all focused on factors influencing IPO initial returns. Among these, the aftermarket risk is found to have a positive impact on IPO initial returns. On the other hand, theoretical derivation by Sherman (2005) found that there might exist a negative relationship between the fluctuation of individual stock returns after IPO and initial returns. Regardless of the underwriting methods, they found that a stock with a lower anticipated underpricing would show higher IPO post-market individual stock returns fluctuations. However, Pettway et al. (2008) based on the model of Sherman's and applied empirical data of Japan to discuss the influence of the IPO initial returns towards the aftermarket fluctuation. Their conclusions were opposite to Sherman's findings, i.e., the IPO initial returns positively influenced the IPO aftermarket risk. Gleason et al. (2008) also regarded initial returns as an independent variable to analyze the influence of an anticipated underpricing towards the fluctuation of short-term and longterm individual stock returns after IPO. Results indicated that the higher the IPO initial returns, the better the reputation of the underwriter, and the higher the IPO aftermarket risk of a venture-backed issuing company.

According to the above-reviewed IPO-related literature, there may exist simultaneous relationship between IPO initial returns and aftermarket risk. The purpose of this study is to utilize the Three Stage Least Squares (3SLS) of the simultaneous equation estimation method to analyze the cross relationship between IPO initial returns and aftermarket risk. We will estimate the structural form equation system of IPO initial returns and aftermarket risk equations first in order to test and obtain the structural form coefficients. The analytically derived reduced form (ADRF) coefficients will then be calculated to analyze the net effects of each exogenous variable on two endogenous variables.

\section{MODEL SPECIFICATION, VARIABLE DEFINITION, AND DATA DESCRIPTION}

\subsection{IPO initial returns structural form equation specification}

The first structural form equation of the simultaneous equation system is the IPO initial returns equation. IPO initial returns $I R$ are defined and calculated as $I R_{i}=\left(P_{i, t}-P_{0}\right) / P_{0}$, where $P_{i, t}$ is the closing price of the $t$ day of IPO stock $i$ and $P_{0}$ is the underwriting price of IPO stock. We specify IPO initial returns as follows:

$$
\begin{aligned}
& I R_{i}=\beta_{0}+\beta_{1} U N D_{i}+\beta_{2} A U D_{i}+ \\
& +\beta_{3} V C_{i}+\beta_{4} R_{S S K_{i}}+\beta_{5} L A G D A Y_{i}+ \\
& +\beta_{6} M_{i}+\beta_{7} L N T A_{i}+\beta_{8} B R_{i}+ \\
& +\beta_{9} I N_{i}+\beta_{10} D_{2}+\beta_{11} D_{3}+\varepsilon_{1 i}
\end{aligned}
$$

where $U N D$ and $A U D$ represent the reputation of underwriters and auditing accountants, respectively. If, in the year before IPO, cases underwritten by underwriter are above market average, $U N D$ is 1 ; otherwise it is 0 . If IPO companies are audited by four major accountants in Taiwan, $A U D$ is 1; otherwise it is 0. Following Beatty and Ritter (1986), we believe that the quality of IPO underwriters and auditing accountants will influence investors' impression towards the healthiness of the company. The better the reputation of its underwriter and auditing accountant, the lower the IPO initial returns. $V C$ is the involvement of venture capital. During IPO process, if venture capital provides financial support, then $V C$ is 1; otherwise it is 0 . Chanine et al. (2007) found that, in British IPO market, the more shares held by venture capital, the lower the IPO initial returns. That is, companies with a venture capital background would have lower IPO initial returns. RISK represents IPO aftermarket risk. The proxy variable of IPO aftermarket risk is obtained by calculating the standard deviation of individual stock returns of past 30 trading days starting from the sixth day after IPO, i.e.,

$$
\operatorname{RISK}_{i}=\sqrt{\sum_{t=0}^{30}\left(r_{i, t}-\bar{r}\right)^{2} / t},
$$


where $r_{i, t}=P_{i, t+1}-P_{i, t} / P_{i, t}$ is the return of the $t$ day of the $i$ company and $P_{i, t}$ is defined previously. Following Cassia et al. (2004) and Peng and Wang (2007), we hypothesize that there exists a positive relationship between aftermarket risk and IPO initial returns. $M$ represents the market power and is defined as

$$
M_{i}=\left[\prod_{p=0}^{T}\left(1+r_{p}\right)\right]-1,
$$

where $r_{p}$ is the market rate of return in day $p$. When $p=0$, it is the date of underwriting and if $p=T$, it is the date of listing in the market. Empirical study by Peng and Wang (2007) had found that the better the market prosperity before IPO, the higher the IPO initial returns.

LNTA represents the size of the company using the total assets of the year before IPO as its proxy. Following Ritter (1984), we hypothesize that the size of the company is negatively related to IPO initial returns. $B R$ is the winning rate of IPO lottery. Following Ritter (1991) and Yeh, Shu, and Guo (2008), we hypothesize that IPO initial returns are negatively related to the winning rate of IPO lottery. IN is the total percentage of shares held by directors. According to the empirical quantile regression results of Lee (2008), total percentage of shares held by directors is negatively related to IPO initial returns.

Lastly, $D_{2}$ and $D_{3}$ are the dummy variables representing different IPO underwriting system in Taiwan, respectively. The underwriting systems in Taiwan include public offering, public offering and auction $\mathrm{D}_{2}$ and book building or a half public offering and a half book building $D_{3}$. We hypothesize that IPO initial returns will be lower with auction or book building system.

\subsection{Aftermarket risk structural form equation specification}

The second equation of the simultaneous equation system is the IPO aftermarket risk structural form equation. While most previous literature focused on IPO initial returns, this study will turn attention to IPO aftermarket risk as well. As mentioned, Pettway et al. (2008) and Gleason et al. (2008) already found that IPO initial returns will also affect IPO aftermarket risk. Moreover, variables of deviation between seat control and voting right and deviation between voting right and cash right will also be considered in the model to investigate the importance of corporate governance on aftermarket risk. The specification of the equation is as follows:

$$
\begin{aligned}
& \text { RISK }_{i}=\alpha_{0}+\alpha_{1} I_{i}+\alpha_{2} \text { SEO }_{i}+ \\
& +\alpha_{3} \text { SEATCON }_{i}+\alpha_{4} \text { CONCASH }_{i}+ \\
& +\alpha_{5} \text { BH }_{i}+\alpha_{6} S_{i}+\alpha_{7} \text { LNYEAR }_{i}+ \\
& +\alpha_{8} \text { ROA }_{i}+\alpha_{9} \text { LNS }_{i}+\alpha_{10} \text { DR }_{i}+ \\
& +\alpha_{11} D_{2}+\alpha_{12} D_{3}+\varepsilon_{2 i}
\end{aligned}
$$

where RISK and IR is the IPO aftermarket risk and initial returns, respectively, defined previously. We expect IPO initial returns to be positively correlated to aftermarket risk (Pettway et al., 2008; Gleason et al., 2008). SEO is a dummy variable representing IPO companies with or without seasoned equity offering in one year. We expect the correlation between $S E O$ and aftermarket risk to be negative.

SEATCON is the deviation between seat control and voting right and is calculated as the difference between the percentage of directors under control and the percentage of voting right of share-holding. The higher is the deviation, the weaker is the corporate governance and, thus, the riskier firm is facing (Lin \& Chang, 2009). CONCASH is the deviation between voting right and cash right, one of the other corporate governance variables considered, and is also expected to be positively correlated to RISK (Lin \& Chang, 2009).

BH refers to the percentage of shares held by external large shareholders. Brennan and Franks (1997) pointed out that the more shares held by external shareholders, the less risky firms will be. $S$ represents the market volatility before IPO and is defined as

$$
S_{i}=\sqrt{\sum_{p=0}^{T}\left(r_{p}-r_{0}\right)^{2} / T},
$$

where $r_{p}$ is the market rate of return in day $\mathrm{p}$. When $p=0$, it is the date of public underwriting and when $p=T$, it is the date of listing in the market. LNYEAR is the age of company from its establishment to public offering. According to 
Pettway et al. (2008) on Japanese empirical study, the longer is the firm established, the lower aftermarket risk. $R O A$ is the return on assets in previous year. It is expected to be negatively correlated to aftermarket risk.

Variable LNS represents the size of IPO. According to Cassia et al. (2004) and Peng and Wang (2007), LNS is expected to be negatively correlated to aftermarket risk. $D R$ is the debt ratio and is expected to be positively correlated to aftermarket risk. Lastly, $D_{2}$ and $D_{3}$ are dummy variables representing different IPO underwriting systems in Taiwan, respectively, as before.

\subsection{Data description}

The descriptive statistics of all variables are shown in Table 1. As shown, the average of IPO initial returns $I R$ is $12.60 \%$ with a maximum value of $726.09 \%$ and a minimum value of $-77.68 \%$. In other words, for years between 1997 and 2008, investors of Taiwan 637 IPO companies, on average, enjoyed more than $12 \%$ of initial returns. However, high standard deviation of $42.79 \%$ indicates large variation in IPO initial returns. The average of IPO aftermarket risk RISK is $3.32 \%$ with small standard deviation of $1.13 \%$ indicating that the stock return volatility after IPO is somewhat moderate and less deviate. Descriptive statistics for some other important variables include average premarket volatility $S$ is $1.6 \%$ with lower standard deviation of $1.10 \%$, average market return before IPO $M$ is as low as $0.25 \%$ with relatively high standard deviation of $9 \%$, average $R O A$ is relatively high of $16.86 \%$ with relatively moderate standard deviation of $10.56 \%$, average winning rate of IPO lottery $B R$ is $22.36 \%$ with $35.72 \%$ standard deviation, and average percentage of shares held by directors $I N$ is $36.08 \%$ with relatively low standard deviation of $18.23 \%$.

\section{EMPIRICAL RESULTS DISCUSSION}

As mentioned previously, there exists a cross relationship between IPO initial returns and aftermarket risk. The purpose of this study is to utilize the Three Stage Least Squares (3SLS) of the simultaneous equation estimation method to analyze the cross relationship between IPO initial returns and aftermarket risk. A structural form equation system of IPO initial returns and after market risk equations is estimated first to obtain the structural form coefficients. The analytically derived

Table 1. Descriptive statistics for all variables

Source: Computed by the researchers using EViews 8.0 .

\begin{tabular}{|c|c|c|c|c|c|}
\hline Variable & Mean & Median & Standard deviation & Minimum & Maximum \\
\hline IR & 0.1260 & 0.0667 & 0.4279 & -0.7768 & 7.2609 \\
\hline SEATCON & 0.1268 & 0.1305 & 0.2079 & -0.5062 & 0.7898 \\
\hline CONCASH & 0.0816 & 0.0285 & 0.1328 & 0.0000 & 0.7673 \\
\hline $\mathrm{BH}$ & 0.1734 & 0.1697 & 0.1253 & 0.0000 & 0.6403 \\
\hline RISK & 0.0332 & 0.0322 & 0.0113 & 0.0072 & 0.0828 \\
\hline$S$ & 0.0160 & 0.0145 & 0.0110 & 0.0027 & 0.2404 \\
\hline$\angle A G D A Y$ & 26.1036 & 27.0000 & 9.5891 & 2.0000 & 127.0000 \\
\hline$M$ & 0.0025 & 0.0008 & 0.0900 & -0.3608 & 0.4424 \\
\hline$\angle N Y E A R$ & 2.4952 & 2.5396 & 0.6441 & 0.1636 & 3.9809 \\
\hline$R O A$ & 0.1686 & 0.1467 & 0.1056 & -0.2236 & 0.6707 \\
\hline LNS & 12.1591 & 11.9428 & 1.1372 & 9.9572 & 18.8940 \\
\hline$D R$ & 0.3772 & 0.3635 & 0.1560 & 0.5040 & 0.8835 \\
\hline LNTA & 14.1046 & 13.9193 & 0.9706 & 11.9309 & 19.9900 \\
\hline$B R$ & 0.2236 & 0.3290 & 0.3572 & 0.0000 & 1.0000 \\
\hline IN & 0.3608 & 0.3180 & 0.1823 & 0.0000 & 1.0000 \\
\hline
\end{tabular}

Note: IR represents IPO initial returns, SEATCON is the deviation between seat control and voting right, CONCASH is the deviation between voting right and cash right, $B H$ refers to the percentage of shares held by external large shareholders, RISK represents IPO aftermarket risk, $S$ represents the market volatility before IPO, $M$ represents the market power, LNYEAR is the age of company from its establishment to public offering, $R O A$ is the return on assets in previous year, LNS represents the size of IPO, DR is the debt ratio, LNTA represents the size of the company, BR is the winning rate of IPO lottery, and IN is the total percentage of shares held by directors. The definition of each variable is described in subsections 2.1 and 2.2. 
reduced form (ADRF) coefficients are then calculated to analyze the net effects of each exogenous variable on two endogenous variables.

\subsection{SLS estimation results of IPO initial return structural form equation}

The 3SLS estimation result of IPO initial return structural form equation and its associated expected sign of each independent variable are shown in Table 2. As shown, most independent variables, including $U N D, R I S K, L A G D A Y, M$, and $B R$, are found to be statistically significantly related to IPO initial returns and are consistent with the expected signs. The above results are the same as findings of Peng and Wang (2007), Yu and Tse (2006), Lee et al. (1996) and Yeh et al. (2008).

Table 2. 3SLS estimation results of IPO initial return structural form equation

Source: Computed by the researchers using EViews 8.0.

\begin{tabular}{|c|c|c|c|}
\hline Variable & $\begin{array}{c}\text { Expected } \\
\text { sign }\end{array}$ & $\begin{array}{c}\text { Coefficient } \\
\text { estimated }\end{array}$ & $t$-statistic \\
\hline CONSTANT & $N / A$ & -0.04726 & -0.16 \\
\hline$A \cup D$ & - & -0.00978 & -0.30 \\
\hline UND & - & $-0.04982^{*}$ & -1.68 \\
\hline VC & - & 0.008671 & 0.27 \\
\hline RISK & + & $10.18765^{*}$ & 1.95 \\
\hline LAGDAY & - & $-0.00382 *$ & -1.90 \\
\hline M & + & $0.491291^{* * *}$ & 2.86 \\
\hline LNTA & - & -0.00804 & -0.48 \\
\hline$B R$ & - & $-0.09477^{* *}$ & -2.03 \\
\hline IN & - & 0.049305 & 0.56 \\
\hline$D_{2}$ & - & 0.038166 & 0.60 \\
\hline$D_{3}$ & - & $0.335535^{* * *}$ & 7.56 \\
\hline
\end{tabular}

Note: ${ }^{* \star \star},{ }^{* \star}$, and ${ }^{\star}$ represent significance level of $1 \%, 5 \%$, and $10 \%$, respectively. The definition of each variable is described in the end note of Table 1.

Specifically, the variable of aftermarket risk (RISK) is positively correlated to IPO initial returns at $10 \%$ significance level as expected. In other words, the higher the aftermarket risk, the higher are the IPO initial returns. Variables of AUD, VC, LNTA, $I N$, and $D_{2}$ are, however, not statistically significant. Variable $D_{3}$ is found to be negatively correlated to IPO initial returns at $1 \%$ significance level and is not consistent with the expected sign. This result indicates that IPO initial returns may not be lower with auction or book building underwriting system in Taiwan.

\subsubsection{SLS estimation results of aftermarket risk structural form equation}

The 3SLS estimation result of aftermarket risk structural form equation and its associated expected sign of each independent variable are shown in Table 3. As shown, most independent variables, including $I R$, SEATCON, BH, S, and LNYEAR are found to be statistically significantly related to aftermarket risk and are consistent with the expected signs. Specifically, variable of IPO initial returns $(I R)$ is positively correlated to aftermarket risk at $5 \%$ significance level as expected. In other words, the higher are the IPO initial returns, the higher is the aftermarket risk. This result is consistent with findings of Pettway et al. (2008) and Gleason et al. (2008).

Table 3. 3SLS estimation results of aftermarket risk structural form equation

Source: Computed by the researchers using EViews 8.0.

\begin{tabular}{|c|c|c|c|}
\hline Variable & $\begin{array}{c}\text { Expected } \\
\text { sign }\end{array}$ & $\begin{array}{c}\text { Coefficient } \\
\text { estimated }\end{array}$ & $t$-statistic \\
\hline CONSTANT & $N / A$ & $0.040968^{* * *}$ & 6.96 \\
\hline$I R$ & + & $0.008407^{* *}$ & 2.49 \\
\hline SEO & - & $0.003727^{* * *}$ & 3.10 \\
\hline SEATCON & + & $0.005688^{* * *}$ & 2.74 \\
\hline CONCASH & - & $-0.00586^{*}$ & -1.76 \\
\hline $\mathrm{BH}$ & - & $-0.00870^{* *}$ & -2.46 \\
\hline$S$ & + & $0.087431^{* *}$ & 2.32 \\
\hline$\angle N Y E A R$ & - & $-0.00263^{* * *}$ & -3.78 \\
\hline$R O A$ & - & -0.00281 & -0.64 \\
\hline LNS & - & -0.00018 & -0.38 \\
\hline$D R$ & - & -0.00249 & -0.90 \\
\hline$D_{2}$ & - & -0.00162 & -0.86 \\
\hline$D_{3}$ & - & $0.002823^{* *}$ & 2.32 \\
\hline
\end{tabular}

Note: ${ }^{* * *},{ }^{* *}$, and ${ }^{*}$ represent significance level of $1 \%, 5 \%$, and $10 \%$, respectively. The definition of each variable is described in the end note of Table 1.

Moreover, variable SEACON, representing the degree of corporate governance, is found to be positively related to aftermarket risk at $1 \%$ significance level as expected. This result is consistent with findings of Yeh et al. (2008). Variables of ROA, $L N S, D R$, and $D_{2}$ are, however, not statistically significant. Variable $S E O$ is found to be significantly related to aftermarket risk with an unexpected positive sign. Result indicates that IPO company with seasoned equity offering in one year may be signaling investors a negative information and, as a result, increasing its aftermarket risk. 
CONCASH, another corporate governance variable, is also found to be significantly correlated to aftermarket risk with an unexpected negative sign, i.e. the more deviate of voting right and cash control right, the less the aftermarket risk. This result indicates that large shareholders are effectively monitoring IPO firm and, as a result, lowering the aftermarket risk of the firm. Variable $D_{3}$ is found positively correlated to aftermarket risk at $1 \%$ significance level and is not consistent with the expected sign. This result indicates that aftermarket IPO stock return volatility may be higher with auction or book building underwriting system in Taiwan.

\subsection{The analytically derived reduced form coefficients of the 3SLS estimation}

In order to find out the net effects of each exogenous variable on IPO initial returns and aftermarket risk, the analytically derived reduced form (ADRF) coefficient of each independent variable is calculated and presented in Table 4. As shown, the net effects or the ADRF coefficients of all exogenous variables on IPO initial returns and aftermarket risk are all with the same signs. This result, as expected, again confirms that IPO initial returns and aftermarket risk will be moving in the same direction when there is shock by any exogenous variable. In terms of the net effect of each exogenous variable on two endogenous variables, we will only discuss those variables with higher significance level in 3SLS structural form equations estimation as follows.

First, for every $1 \%$ decrease in the degree of corporate governance representing by the deviation of seat control and voting right control, the IPO initial returns and aftermarket risk will increase $0.00634 \%$ and $0.0062 \%$, respectively. Second, for every $1 \%$ increase in the percentage of shares held by external large shareholders, the IPO initial returns and aftermarket risk will decrease $0.0969 \%$ and $0.00951 \%$, respectively. Third, for every $1 \%$ increase in the market volatility before IPO, the IPO initial returns and aftermarket risk will increase $0.9741 \%$ and $0.0956 \%$, respectively. Fourth, for every 1 unit increases in the age of the firm, the IPO initial returns and aftermarket risk will decrease $0.029 \%$ and $0.0029 \%$, respectively.

Fifth, using market return to represent market power before IPO, for every $1 \%$ increase in market power, the IPO initial returns and aftermarket risk will increase $0.5373 \%$ and $0.00452 \%$, respectively. Sixth, for every $1 \%$ increases in the winning rate of IPO lottery, the IPO initial returns and aftermarket risk will decrease $0.1036 \%$ and $0.00087 \%$, respectively. All these exogenous shock on IPO initial returns and aftermarket risk above are consistent with the expected signs. Lastly, however, if IPO firm conducts seasoned equity offering in one year, the IPO initial returns and aftermarket risk will unexpectedly increase $0.0415 \%$ and $0.00408 \%$, respectively. And, using book building or a half public offering and a half book building as the underwriting system, the IPO initial returns and aftermarket risk will increase $0.3984 \%$ and $0.00617 \%$, respectively.

Table 4. The analytically derived reduced form coefficients of the 3SLS estimation

Source: Computed by the researchers using EViews 8.0.

\begin{tabular}{|c|c|c|}
\hline \multirow{2}{*}{$\begin{array}{l}\text { Exogenous } \\
\text { variable }\end{array}$} & \multicolumn{2}{|c|}{ Endogenous variable } \\
\hline & $\begin{array}{l}\text { IPO initial } \\
\text { returns }\end{array}$ & $\begin{array}{c}\text { IPO aftermarket } \\
\text { risk }\end{array}$ \\
\hline CONSTANT & 0.4048 & 0.0444 \\
\hline SEO & 0.04150 & 0.00408 \\
\hline SEATCON & 0.06340 & 0.00622 \\
\hline CONCASH & -0.0653 & -0.00641 \\
\hline $\mathrm{BH}$ & -0.0969 & -0.00951 \\
\hline$S$ & 0.97410 & 0.09560 \\
\hline LNYEAR & -0.02930 & -0.00288 \\
\hline$R O A$ & -0.03130 & -0.00307 \\
\hline LNS & -0.00196 & -0.00019 \\
\hline$D R$ & -0.0277 & -0.00271 \\
\hline$A \cup D$ & -0.01070 & -0.00009 \\
\hline UND & -0.05450 & -0.00046 \\
\hline$V C$ & 0.00948 & 0.00008 \\
\hline$\angle A G D A Y$ & -0.00418 & -0.00004 \\
\hline M & 0.53730 & 0.00452 \\
\hline$\angle N T A$ & -0.00880 & -0.00007 \\
\hline$B R$ & -0.1036 & -0.00087 \\
\hline IN & 0.05390 & 0.00045 \\
\hline$D_{2}$ & 0.0237 & -0.00142 \\
\hline$D_{3}$ & 0.3984 & 0.00617 \\
\hline
\end{tabular}

Note: The definition of each variable is described in the end note of Table 1. 


\section{CONCLUSION}

The purpose of this study is to utilize the Three Stage Least Squares (3SLS) of the simultaneous equation estimation method to analyze the cross relationship between IPO initial returns and aftermarket risk. It is the first attempt in literature to investigate the cross relationship between IPO initial returns and aftermarket risk using a total of 637 IPO company data of Taiwan stock market for the period 1997-2008. A structural form equation system of IPO initial returns and aftermarket risk equations is estimated first to obtain the structural form coefficients. The analytically derived reduced form coefficients are then calculated to analyze the net effects of each exogenous variable on two endogenous variables.

Major findings of this study are as follows. First, the signs of the net effects of all exogenous variables on IPO initial returns and aftermarket risk are all the same. In other words, any change in any exogenous variables, IPO initial returns and IPO aftermarket risk will change in the same direction. They are positively correlated, i.e. the higher (lower) the IPO initial returns, the higher (lower) the IPO aftermarket risk.

Second, the less degree of corporate governance, the higher the IPO initial returns and aftermarket risk. For every one percentage deviation of the controlling right vs. voting right, aftermarket risk will increase to $0.0062 \%$, while IPO initial returns will increase to $0.0634 \%$. For every external large share-holder holding one more percentage of shares, IPO aftermarket risk will decrease to $0.00951 \%$, while IPO returns will decrease to $0.0969 \%$.

Third, the larger the market risk before IPO, the larger the IPO initial returns and aftermarket risk. Every $1 \%$ increase in market return volatility, IPO initial returns and aftermarket risk will increase to $0.9741 \%$ and to $0.0956 \%$, respectively. For every $1 \%$ increase in the market power during public offering period, IPO initial returns will increase to $0.5373 \%$, while aftermarket risk will increase to $0.00452 \%$.

Fourth, the longer is the establishment of the company and the higher winning rate of IPO lottery, the less are the IPO initial returns and aftermarket risk. Fifth, using book building or a half public offering and a half book building as the underwriting system, the IPO initial returns and aftermarket risk will be higher. Lastly, if IPO companies conduct seasoned equity offering in one year, IPO initial returns and aftermarket risk will increase to $0.0415 \%$ and $0.00408 \%$, respectively.

\section{REFERENCES}

1. Aggarwal, R., \& Rivoli, P. (1990). Fads in the Initial Public Offering Market? Financial Management, 19(4), 45-57. Retrieved from https://www.jstor.org/ stable/3665609?seq=1\#page_scan_ tab_contents

2. Baron, D. P. (1982). A Model of the Demand for Investment Banking Advising and Distribution Services for New Issues. Journal of Finance, 37(4), 955-976. Retrieved from https://www.jstor.org/ stable/2327760?seq=1\#page_scan_ tab_contents

3. Beatty, R. P., \& Ritter, J. R. (1986). Investment
Banking, Reputation, and the Underpricing of Initial Public Offerings. Journal of Financial Economics, 15(1-2), 213-232. http://dx.doi.org/10.1016/0304405X(86)90055-3

4. Booth, J. R., \& Smith, R. L. (1986). Capital Raising, Underwriting and the Certification Hypothesis. Journal of Financial Economics, 15(1-2), 261-281. https://doi.org/10.1016/0304405X(86)90057-7

5. Boulton, T. J., Smart, S. B., \& Zutter, C. J. (2017). Conservatism and International IPO Underpricing. Journal of International Business Studies,
48(6), 763-785. Retrieved from https://link.springer.com/article/10.1057/s41267-016-0054-8

6. Bouzouita, N., Gajewski, J., \& Gresse, C. (2015). Liquidity Benefits from IPO Underpricing: Ownership Dispersion or Information Effect. Financial Management, 44(4), 785-810. https://doi.org/10.1111/fima.12085

7. Brennan, M. J., \& Franks, J. (1997). Underpricing, Ownership and Control in Initial Public Offerings of Equity Securities in the UK. Journal of Financial Economics, 45(3), 391-413. https://doi.org/10.1016/S0304405X(97)00022-6 
8. Carter, R., \& Manaster, S. (1990). Initial Public Offerings and Underwriter Reputation. Journal of Finance, 45(4), 1045-1067. https://doi.org/10.2307/2328714

9. Cassia, L., Giudici, G., Paleari, S., \& Redondi, R. (2004). IPO Underpricing in Italy. Applied Financial Economics, 14(3), 179-194. https://doi.org/10.1080/0960310042000187333

10. Chalk, A. J., \& Peavy, J. W. (1987). Initial Public Offerings: Daily Returns, Offering Types, and the Price Effect. Financial Analysts Journal, 43(5), 65-69. Retrieved from https://www.jstor.org/ stable/4479063

11. Chanine, S., Filatotchev, I., \& Wright, M. (2007). Venture Capitalists, Business Angels, and Performance of Entrepreneurial IPOs in the UK and France. Journal of Business Finance and Accounting, 34(3-4), 505-528. https://doi.org/10.1111/j.14685957.2007.02045.x

12. Chemmanur, T. J. (1993). The Pricing of Initial Public Offerings: A Dynamic Model with Information Production. The Journal of Finance, 48(1), 285-304. https://doi.org/10.2307/2328890

13. Chowdhry, B., \& Nanda, V. (1996). Stabilization, Syndication, and Pricing of IPOs. Journal of Financial and Quantitative Analysis, 31(1), 25-42. Retrieved from https://econpapers.repec.org/ article/cupjfinqa/v_3a31_3ay_3a1 996_3ai_3a01_3ap_3a25-42_5f00. htm

14. Davidson, R., \& MacKinnon, J. G. (1989). Testing for Consistency Using Artificial Regressions. Econometric Theory, 5(3), 363-384 Retrieved from https://www.jstor. org/stable/3532374?seq=1\#page_ scan_tab_contents

15. Davidson, R., \& MacKinnon, J. G. (1995). Estimation and Inference in Econometrics. Econometric Theory, 11(3), 631-635. https://doi. org/10.1017/S0266466600009452

16. Deng, Q., \& Zhou, Z. (2016). Overreaction in ChiNext IPOs' Initial Returns: How Much and What Caused It? Emerging
Markets Review, 29, 82-103. https://doi.org/10.1016/j.ememar.2016.08.012

17. Gleason, K., Johnston, J., \& Madura, J. (2008). What Factors Drive IPO Aftermarket Risk? Applied Financial Economics, 18(13-15), 1099-1110. https://doi. org/10.1080/09603100701466062

18. Gompers, P. A. (1996). Grandstanding in the Venture Capital Industry. Journal of Financial Economics, 42(1), 133156. https://doi.org/10.1016/0304405X(96)00874-4

19. Hausman, J. A. (1978). Specification Tests in Econometrics. Econometrica, 46(6), 1251-1271. https://doi. org/10.2307/1913827

20. Komenkul, K., Sherif, M., \& Xu, B. (2017). IPOs' Signalling Effects for Speculative Stock Detection: Evidence from the Stock Exchange of Thailand. Applied Economics, 49(31), 3067-3085. https://doi.org/ 10.1080/00036846.2016.1254338

21. Lee, J. S. (2008). The Determinants of IPO Underpricing: Application of Quantile Regression. Review of Securities \& Futures Markets, 20(1), 47-100 (published in Chinese). Retrieved from https://db1n.sinica. edu.tw/textdb/tssci/listsrchpr. php?_op=?paperID:16399

22. Lee, P. J., Taylor, S. L., \& Walter, T. S. (1996). Australian IPO Pricing in the Short and Long Run. Journal of Banking and Finance, 20(7), 11891210. https://doi.org/10.1016/03784266(95)00053-4

23. Lin, C. J., \& Chang, C. C. (2009). Abnormal Change of Board Members, Family Firms and Fraud. The International Journal of Accounting Studies, 48, 1-33 (published in Chinese). Retrieved from https://db1n.sinica.edu. tw/textdb/tssci/listsrchpr.php? op=?paperID:17943

24. Ma, T., \& Hu, T. C. (2003). The Determination of Underwriting Mechanisms and It's Impact on IPO Discount: Auction, Bookbuilding and Fixed Price. Journal of Financial Studies, 11(1), 1-40 (published in Chinese). Retrieved from http://www.jfs.org.tw/
index.php/jfs/article/viewArticle/2011138

25. Malhotra, M., \& Nair, M. (2105). Initial Public Offerings' Underpricing: A Study on the Short Run Price Performance of Book-Built IPOs in India. ParipexIndian Journal of Research, 4(2), 8. Retrieved from https://papers.ssrn. com/sol3/papers.cfm?abstract_ id $=2572348$

26. Peng, Y., \& Wang, K. (2007) IPO Underpricing and Floatation Methods in Taiwan: A Stochastic Frontier Approach. Applied Economics, 39(1921), 2785-2796. https://doi org/10.1080/00036840600749417

27. Pettway, R. H., Thosar, S., \& Walker, S. (2008). Auctions Versus Book-built IPOs in Japan: A Comparison of Aftermarket Volatility. Pacific-Basin Finance Journal, 16(3), 224-235. https://doi. org/10.1016/j.pacfin.2007.04.010

28. Raharja, B., Suhaeli, D., \& Mranani, M. (2017). Research of the Stock Price Overreaction and Investor Overconfidence Issues. Business, Management and Education, 15, 127-139. Retrieved from https:// www.ceeol.com/search/articledetail id $=549392$

29. Ritter, J. R. (1984). The "Hot Issue" Market of 1980. Journal of Business, 57(2), 215-240. Retrieved from https://www.jstor.org/ stable/2352736?seq=1\#page_scan_ tab_contents

30. Ritter, J. R. (1991). The Longrun Performance of Initial Public Offerings. Journal of Finance, 46(1), 3-27. https://doi. org/10.1111/j.1540-6261.1991. tb03743.x

31. Rock, K. (1986). Why New Issues Are Underpriced. Journal of Financial Economics, 15(1-2), 187 212. https://doi.org/10.1016/0304405X(86)90054-1

32. Ruud, J. S. (1993). Underwriter Price Support and the IPO Underpricing Puzzle. Journal of Financial Economics, 34(2), 135151. https://doi.org/10.1016/0304405X(93)90015-4

33. Sherman, A. E. (2005). Global Trends in IPO Methods: Book Building versus Auctions with 
Endogenous Entry. Journal of Financial Economics, 78(3), 615649. https://doi.org/10.1016/j. jfineco.2004.09.005

34. Smith, C. W. Jr. (1986). Investment Banking and the Capital Acquisition Process. Journal of Financial Economics, 15(1-2), 3-29. https://doi.org/10.1016/0304405X(86)90048-6

35. Vakrman, T., \& Kristoufek, L. (2015). Underpricing, Underperformance and Overreaction in Initial Public Offerings: Evidence from Investor Attention Using Online
Searches. Springerplus, 4, 84. https://dx.doi.org/10.1186\%2 Fs40064-015-0839-4

36. Welch, I. (1989). Seasoned Offerings, Imitation Costs, and the Underpricing of Initial Public Offerings. Journal of Finance, 44(2), 421-449. https://doi. org/10.2307/2328597

37. Yeh, Y., Shu, P., \& Guo, R. (2008). Ownership Structure and IPO Valuation Evidence from Taiwan. Financial Management, 37(1), 141-161. Retrieved from https://www.jstor.org/ stable $/ 30130500$ ?seq=1\#page scan tab contents

38. Yu, T., \& Tse, Y. K. (2006). An Empirical Examination of IPO Underpricing in the Chinese A-share Market. China Economic Review, 17(4), 363-382. https://doi org/10.1016/j.chieco.2005.07.001

39. Zhou, L., \& Sadeghi, M. (2019). The Impact of Innovation on IPO Short-term Performance - Evidence from the Chinese Markets. Pacific-Basin Finance Journal, 53, 208-235. https://doi. org/10.1016/j.pacfin.2018.10.010 